\title{
Assessment of tolerances in Mitragyna parvifolia (Roxb.) Korth. and Syzygium cumini Keels. seedlings to waterlogging
}

\author{
A. BIDALIA ${ }^{+}$, Z. OKRAM, M. HANIEF, and K.S. RAO \\ Department of Botany, University of Delhi, New Delhi 110007, India
}

\begin{abstract}
Waterlogging is one of the critical factors controlling the distribution, regeneration, and survival of vegetation in wetlands. Here, we tested the hypothesis that Mitragyna parvifolia (Roxb.) Korth. and Syzygium cumini Keels, inhabiting the Keoladeo National Park, a Ramsar wetland (Bharatpur, India), are tolerant to waterlogging. The morphological and photosynthetic variables of four-month-old seedlings subjected to waterlogging, along with the concentrations of macroand micronutrients, were examined. After 35 days, treatment was halted due to high mortality of S. cumini seedlings in contrast to that of M. parvifolia seedlings. Significant declines in most of the studied variables were observed in both species when compared with their respective controls. In addition, M. parvifolia seedlings developed adventitious roots and lenticels and showed an increased root biomass. Based on the results, we concluded that adaptive traits displayed by M. parvifolia seedlings facilitate its tolerance to waterlogging in contrast to $S$. cumini seedlings.
\end{abstract}

Additional key words: adventitious roots; chlorophyll $a$ fluorescence; gas exchange; lenticels.

\section{Introduction}

Climate change is anticipated to alter the hydrological cycle, which can consequently change the patterns of precipitation and timing of wet and dry seasons globally (Arnell 1999). The increased frequency in extreme precipitation events increases the risks of flooding in most densely populated and low-lying areas, particularly within the Asian and African continents (Parry et al. 2007). These changes in the hydrological cycle occurring because of climate change (Erwin 2009) along with human interference (Bassi et al. 2014) have had adverse effects on wetlands worldwide. The success of wetland restoration programs largely depends upon several factors, such as the wetland area, wetland type, degree of damage, hydrology of the catchment, land use of the catchment, and ecological function(s) of interest (Kentula 2000). In addition, each wetland plant has a different water requirement and tolerance, which further depends on the age of the plant (Middleton 2002). Flooding, which results in waterlogging (short or long duration) and full submergence (short or long duration, shallow or deep), creates a selection pressure for many traits of terrestrial wetland plants (Colmer and Voesenek 2009), and such interspecific variation strongly impacts species abundance and distribution in flood-prone areas (Bailey-Serres and Voesenek 2008). Nevertheless, flooding is a common phenomenon in wetland ecosystems, gallery forests, and some regions of high rainfall and poor soil drainage (Pezeshki 1994, Kozlowski 1997).

The effective management of natural areas, forests, and agricultural fields depends on the development of various methods to assess plant variables, such as physiological conditions, plant viability, and the presence of plant stress under various environmental conditions (Goltsev et al. 2016). A physiological knowledge of plants is required to understand the habitat requirements of native, endangered, and exotic species; however, this knowledge also underlies the understanding of the fundamental niche of a species, which can help in predicting plant response to climate

Received 10 December 2016, accepted 6 March 2017, published as online-first 8 April 2017.

${ }^{+}$Corresponding author; e-mail: bidaliaankita@gmail.com

Abbreviations: $\mathrm{Chl}$ - chlorophyll; $\mathrm{ChlF}$ - chlorophyll fluorescence; $E$ - transpiration rate; $\mathrm{F}_{0}$ - minimal fluorescence yield of the darkadapted state; $\mathrm{F}_{\mathrm{m}}$ - maximal fluorescence yield of the dark-adapted state; $\mathrm{F}_{\mathrm{v}} / \mathrm{F}_{\mathrm{m}}$ - maximal quantum yield of PSII photochemistry; $g_{\mathrm{S}}$ - stomatal conductance; KNP - Keoladeo National Park; LA - leaf area; $P_{\mathrm{N}}$ - net photosynthetic rate; MC - M. parvifolia control; MW - M. parvifolia waterlogged; SC - S. cumini control; SW - S. cumini waterlogged; WUE - water-use efficiency $\left(=P_{\mathrm{N}} / E\right)$.

Acknowledgements: We are thankful to the Forest Department of the state of Rajasthan (India) for providing permission to collect seeds, the University Grant Commission (UGC), India, and University of Delhi for financial support. We also thank to Dr. Chirashree Ghosh, Department of Environmental Studies, University of Delhi, for research facility. The authors would like to thank Enago (www.enago.com) for English language review. 
change (van Kleunen 2014). Measures, such as photosynthetic capacity, respiration, or transpiration in plants, which incorporate many physiological systems, might directly reflect the fitness of a plant at an individual level; therefore, conservation physiology can help to monitor threats to biodiversity and to predict response to climate change by determining the physiological tolerance of a plant (Cooke and O'Connor 2010). Leaf or canopy gas exchange along with chlorophyll (Chl) fluorescence (ChlF) provides information on a wide range of key biophysical and biochemical limitations to photosynthesis in vivo (Long and Bernacchi 2003). The ChlF measurement may be considered as a powerful tool to assess plant vitality under unfavorable conditions because it is simple, noninvasive, reliable, powerful, inexpensive, and a rapid tool to analyze photosynthetic light-dependent reactions (Dąbrowski et al. 2016, Kalaji et al. 2016). Hence, these measures are used in various fields, such as agriculture, ecology, and environmental studies, for example, photosynthetic adaptability of rye grass varieties to long-term shade (Dąbrowski et al. 2015), photosynthetic acclimation in tor grass (Bąba et al. 2016), water and drought stress in barley mutants (Janeczko et al. 2016), and gas exchange, delayed $\mathrm{Chl}$ in a fluorescent ryegrass under salt stress (Dąbrowski et al. 2017).

The deleterious effect of flooding occurs because of the anaerobic conditions created in the soil, which result in an "energy crisis" in the root zone area of plants (Armstrong et al. 1994, Colmer and Voesenek 2009). Flooding also alters the physical, chemical, and biological conditions within the soil (Pezeshki 1994, 2001). Flooding or waterlogging results in the saturation of soil pores, thereby reducing soil oxygen, which may affect aerobic respiration (Lambers et al. 2008). Moreover, seedlings are found to be more sensitive to waterlogging than older plants (Kozlowski 1984). The effects of flooding on plants include the disruption of the carbon-water balance; decreases in the root system, photosynthetic rate, stomatal conductance, and leaf growth, destruction of Chl, premature leaf senescence, abscission, changes to biomass partitioning, and decreases in mineral and water absorption due to lowered root hydraulic conductivity. However, an increase in ethylene and reactive oxygen species is also observed (Drew 1997, Kozlowski 1997, Pezeshki 2001, Mielke et al. 2003, Lambers et al. 2008, Ashraf 2012, Verma et al. 2012, Insausti and Gorjón 2013). Considered together, these changes alter the morphology, physiology, and anatomy of plants, depending upon the species (Pezeshki 1994, Blom and Voeseneck 1996, Kozlowski 1997).

Keoladeo National Park (KNP), Bharatpur, Rajasthan,

\section{Materials and methods}

Plant material and waterlogging treatment: During May 2014, seeds were collected from M. parvifolia and S. cumini in KNP $\left(27^{\circ} 7^{\prime} 6^{\prime \prime}-27^{\circ} 12^{\prime} 2^{\prime \prime N}\right.$ and $77^{\circ} 29^{\prime} 5^{\prime \prime}-$
India, is a United Nations World Heritage Site, a Ramsar wetland of ecological importance, and a managed wetland. Frequent droughts and water scarcity have distressed the hydrology of the park, thus disturbing its ecology (Brar 1996). Furthermore, approximately a century ago, the wetland was carved out of the floodplain of two seasonal rivers (Ghambir and Banganga) (Chauhan and Gopal 2001); however, at present, the creation of embankments along the rivers and other land uses within the catchment have threatened this wetland (Gopal 2013). Mitragyna parvifolia (Roxb.) Korth. of the family Rubiaceae and Syzygium cumini Keels. of the family Myrtaceae are two predominant and ecologically important plant species within the park. M. parvifolia represents a climax community of swamp/riverbed vegetation (Mathur et al. 2010); however, a decline in the population of M. parvifolia has been observed in this wetland area (Middleton 2009), and this species is listed as an endangered species of Rajasthan due to its overexploitation and habitat destruction (Panwar and Tarafdar 2006). Although S. cumini is a pantropical species, which can colonize ravines, degraded land, and waterlogged areas (Hiwale 2015), it is reported to be susceptible to waterlogging (Nema and Khare 1992).

In order to maintain the wetland, the forest department of Rajasthan, India, has adopted several initiatives, such as the construction of dykes and impoundments in the park to inundate the wetland areas, eradication of invasive species, establishment of forest nurseries, rural appraisal programs to raise awareness of wetlands among people, and encouraging research to protect both the flora and fauna of the park. In our field survey in 2012, we observed a good germination of both species within the park; however, a lower number of saplings were observed for $M$. parvifolia as compared to S. cumini. In addition, most of the seedlings observed during the survey were situated within the shade of trees, shrubs, and grasses.

Terrestrial wetland plant species have been observed to withstand flooding conditions by the development of various strategies, even allowing them to thrive under such conditions (Banach et al. 2009, Pucciariello et al. 2014). Moreover, the degree of flooding tolerance varies among species, which further depends upon flooding and plant conditions, such as time, depth and duration, plant age, and edaphic factors (Kozlowski 1984, Ewing 1996). Hence, in the present study, we hypothesized that M. parvifolia and S. cumini inhabiting a KNP wetland can tolerate flooding/ waterlogging. Therefore, its seedlings can survive and become established under waterlogged conditions. Moreover, as available literature shows, no attempt has been made to date to study the waterlogging tolerance of M. parvifolia and S. cumini at the seedling stage.

$\left.77^{\circ} 33^{\prime} 9 " \mathrm{E}\right)$, then the seeds were grown in the garden of the University of Delhi, India, during July 2014. After germination, seedlings were potted in 5-L pots containing 
an autoclaved mixture of sand, organic manure, and garden soil $(1: 1: 4)$, and then transferred to a growth chamber. Based on field observations, the air temperature and relative humidity were maintained at $30 / 28^{\circ} \mathrm{C}$ (day/night) and $80-85 \%$, respectively, with a PPFD of $600 \mu \mathrm{mol}$ (photon) $\mathrm{m}^{-2} \mathrm{~s}^{-1}$ with a $12 / 12 \mathrm{~h}$ (light/dark) photoperiod. Waterlogging was imposed by immersing the pots containing four-month-old seedlings into a tub filled with water up to $8 \mathrm{~cm}$ below the top edge of the pot. The water in the pots was topped up as the water levels dropped, whereas seedlings in the control treatment were watered every third day $(650 \mathrm{~mL})$.

Plant growth measurements: Seedling height was measured weekly with a measuring scale, whereas leaf area (LA) was calculated by drawing a leaf outline on a graph paper with a pencil and counting the enclosed squares at the end of the experiment.

Plant biomass: The leaves, stems, and roots of the seedlings were harvested after completion of the experiment (35 d), immediately weighed for fresh mass (FM), and then dried in an oven at $60^{\circ} \mathrm{C}$ until a constant mass was achieved for the measurement of dry mass (DM), following which biomass was calculated.

Plant nutrient analysis: The dried leaf, stem, and root samples were ground to a fine powder, then $0.50 \mathrm{~g}$ of the powdered sample was digested in a nitric acid:perchloric acid (1:5) solution (Allen 1974) prior to analysis. The concentrations of $\mathrm{Na}^{+}$and $\mathrm{K}^{+}$were determined using a flame photometer (Systronics, Flame Photometer 128, India). Carbon and nitrogen were determined using a CHNS analyzer (Vario, Micro-cube, Elementar, Germany). Extractable phosphorous was determined colorimetrically by the ammonium molybdate method (Grimshaw 1974), whereas trace elements were analyzed by an atomic absorption spectrophotometer (GBC sense AA, Dual, USA).

Leaf gas exchange and measurement of $\mathrm{Chl} \boldsymbol{a}$ fluorescence: All measurements of the leaf gas exchange were conducted weekly on mature and fully expanded leaves throughout the experimental period between 8:00 and $12: 30 \mathrm{~h}$. Light-response curves were constructed to determine the light-saturated rates of photosynthesis, following which all measurements were carried out at PPFD of $1,000 \mu \mathrm{mol}$ (photon) $\mathrm{m}^{-2} \mathrm{~s}^{-1}$ using a $2-\mathrm{cm}^{2}$ chamber of $\mathrm{Li}$-Cor $6400 X \mathrm{~T}$ with a red-blue light-emitting diode light

\section{Results}

Growth and survival: After $35 \mathrm{~d}$ of waterlogging, 90\% mortality was observed in S. cumini seedlings compared to $0 \%$ mortality in M. parvifolia seedlings. Yellowing of leaves was observed in both species. However, M. parvifolia seedlings developed hypertrophied lenticels source (Li-Cor, Lincoln, Nebraska, USA) (Bidalia et al. 2016). The net photosynthetic rate $\left(P_{\mathrm{N}}\right)$, stomatal conductance to water vapor $\left(g_{\mathrm{s}}\right)$, and the rate of transpiration $(E)$ were measured using the standard equations (von Caemmerer and Farquhar 1981), whereas water-use efficiency was expressed by the $P_{\mathrm{N}} / E$ ratio.

Chl $a$ fluorescence was measured in the same leaves used for measuring gas exchange by the use of the leaf chamber fluorometer Li-Cor 6400XT (Licor-Cor, Lincoln, Nebraska, USA). The leaves were dark-adapted for $30 \mathrm{~min}$, then a pulse of far red light (FR) was applied to the leaf samples to achieve full oxidation of the primary quinone electron acceptor $\mathrm{Q}_{\mathrm{A}}$. Minimal fluorescence $\left(\mathrm{F}_{0}\right)$ was then measured by applying a measuring light $(630 \mathrm{~nm})$ of very low light intensity $\left[<1 \mu \mathrm{mol}\right.$ (photon) $\left.\mathrm{m}^{-2} \mathrm{~s}^{-1}\right]$, which does not induce any significant electron transfer from PSII, whereas the maximal $\left(\mathrm{F}_{\mathrm{m}}\right)$ fluorescence was achieved by administering a saturating flash of light (630 $\mathrm{nm}$ wavelength) $\left[>7,000 \mu \mathrm{mol}\right.$ (photon) $\left.\mathrm{m}^{-2} \mathrm{~s}^{-1}\right]$, which induced maximum fluorescence by PSII (Maxwell and Johnson 2000, Govindjee 2004, Kalaji et al. 2014).

Chl estimation: Total Chl, Chl $a$, and Chl $b$ were determined in the same leaves as those used for measuring gas exchange and Chl $a$ fluorescence. The leaves were immediately stored in ice, then $0.1 \mathrm{~g}$ of the leaves was immersed in $7 \mathrm{~mL}$ of dimethyl sulphoxide, incubated at $80^{\circ} \mathrm{C}$, and the final volume brought up to $10 \mathrm{~mL}$. Optical densities were then measured at 645 and $663 \mathrm{~nm}$ (Hiscox and Israelstam 1979) using a spectrophotometer (Beckman Coulter DU 730, USA). The concentrations of Chl $a$ and Chl $b$ were calculated using the following Arnon (1949) and expressed as $\left[\mathrm{mg} \mathrm{g}^{-1}\right]$ :

$$
\begin{aligned}
& \text { Chl } a=\frac{12.7 \times \mathrm{A}_{663}-2.69 \times \mathrm{A}_{645}}{1000 \times \mathrm{W}} \times \mathrm{V} \\
& \text { Chl } b=\frac{22.9 \times \mathrm{A}_{645}-4.68 \times \mathrm{A}_{663}}{1000 \times \mathrm{W}} \times \mathrm{V}
\end{aligned}
$$

where $A_{645}$ is the absorbance at $645, A_{663}$ is the absorbance at $663, \mathrm{~W}$ is the fresh mass of leaves [g], and $\mathrm{V}$ is the final volume of the solution $[\mathrm{mL}]$.

Statistical analysis: Data were assessed for normality using the Kolmogorov-Smirnov's or Shapiro-Wilk's tests, while an independent $t$-test was used to compare the mean values of the control and the waterlogging treatment of both the species at a 0.05 level of significance $(\alpha)$ using the statistical software package SPSS version 16 (IBM SPSS, NY, USA).

at the base of the stem and adventitious roots emerged from the stem base, whereas no such morphological alterations were observed in S. cumini. Waterlogging treatment significantly reduced the seedling height by $19.1 \%$ in M. parvifolia and $11.4 \%$ in S. cumini compared 
with the controls (Table 1, Fig. 1). LA, which was calculated at the end of the experiment, was also reduced significantly by the waterlogging treatment in both species (Table 2).

Biomass: A decrease in biomass was observed in both species when compared with controls. As compared with the control, significant reductions in leaf and stem biomass of $M$. parvifolia seedlings were observed (24.8 and 35.4\%, respectively), whereas a significant increment was observed in the root biomass $(60.9 \%)$ (Tables 1, 2). However, as compared with the control, the leaf biomass of S. cumini $(25.6 \%)$ did not decline significantly, whereas the reductions in the stem and root biomass were significant ( 74 and $46.3 \%$, respectively) after $35 \mathrm{~d}$ of waterlogging (Tables 1, 2).
Mineral nutrients: The waterlogging treatment resulted in significant decreases in all macronutrients, such as concentrations of $\mathrm{N}, \mathrm{P}, \mathrm{K}, \mathrm{Mg}, \mathrm{Ca}$, and $\mathrm{C}$ in leaves, stems, and roots of both species as compared with the controls (Table 3); however, $\mathrm{P}$ and $\mathrm{N}$ in the leaves and roots did not differ significantly from that of the control in M. parvifolia (Table 3), whereas only $\mathrm{N}$ was significantly different as compared with the control in S. cumini (Table 3).

As compared with the controls, significant decreases in the concentrations of the micronutrients, such as $\mathrm{Na}, \mathrm{Co}$, $\mathrm{Cr}, \mathrm{Cu}, \mathrm{Zn}, \mathrm{Fe}$, and $\mathrm{Mn}$ in leaves, stems, and roots of both species were observed (Table 4), with an exception of a few elements, such as $\mathrm{Na}, \mathrm{Cu}$, and $\mathrm{Zn}$, which did not differ significantly in the stem, and $\mathrm{Cr}$ and $\mathrm{Zn}$ in the roots of M. parvifolia (Table 4), whereas $\mathrm{Cr}$ and $\mathrm{Zn}$ in the stem and $\mathrm{Cu}$ and $\mathrm{Zn}$ in the roots did not differ significantly in S. cumini (Table 4).

Table 1. Difference in the seedlings height, leaf area (LA), leaf, stem, and root biomass, chlorophyll (Chl) $a$, Chl $b$, total Chl, net photosynthetic rate $\left(P_{\mathrm{N}}\right)$, stomatal conductance $\left(g_{\mathrm{s}}\right)$, transpiration rate $(E)$, water-use efficiency (WUE), and maximal quantum efficiency of PSII $\left(\mathrm{F}_{\mathrm{v}} / \mathrm{Fm}_{\mathrm{m}}\right)$ in the seedlings after 35 days of waterlogging treatments compared with controls. MC - Mitragyna parvifolia control; MW - M. parvifolia waterlogged; SC - Syzygium cumini control; SW - S. cumini waterlogged.

\begin{tabular}{|c|c|c|c|c|c|c|c|c|c|c|c|c|c|}
\hline Treatment & $\begin{array}{l}\text { Height } \\
{[\%]}\end{array}$ & $\begin{array}{l}\text { Leaf } \\
\text { area } \\
{[\%]}\end{array}$ & $\begin{array}{l}\text { Leaf } \\
\text { biomass } \\
{[\%]}\end{array}$ & $\begin{array}{l}\text { Stem } \\
\text { biomass } \\
{[\%]}\end{array}$ & $\begin{array}{l}\text { Root } \\
\text { biomass } \\
{[\%]}\end{array}$ & $\begin{array}{l}\text { Chl } a \\
{[\%]}\end{array}$ & $\begin{array}{l}\text { Chl } b \\
{[\%]}\end{array}$ & $\begin{array}{l}\text { Total Chl } \\
{[\%]}\end{array}$ & $\begin{array}{l}P_{\mathrm{N}} \\
{[\%]}\end{array}$ & $\begin{array}{l}g_{\mathrm{s}} \\
{[\%]}\end{array}$ & $\begin{array}{l}E \\
{[\%]}\end{array}$ & $\begin{array}{l}\text { WUE } \\
{[\%]}\end{array}$ & $\begin{array}{l}\mathrm{F}_{\mathrm{v}} / \mathrm{F}_{\mathrm{m}} \\
{[\%]}\end{array}$ \\
\hline MC & 100 & 100 & 100 & 100 & 100 & 100 & 100 & 100 & 100 & 100 & 100 & 100 & 100 \\
\hline MW & 80.89 & 52.50 & 75.21 & 64.57 & 160.87 & 34.99 & 76.39 & 53.71 & 24.32 & 52.50 & 54.91 & 33.98 & 0.96 \\
\hline $\mathrm{SC}$ & 100 & 100 & 100 & 100 & 100 & 100 & 100 & 100 & 100 & 100 & 100 & 100 & 100 \\
\hline SW & 88.55 & 69.36 & 74.39 & 26.00 & 53.36 & 12.87 & 78.30 & 39.89 & 6.09 & 158.20 & 106.11 & 11.81 & 5.26 \\
\hline
\end{tabular}

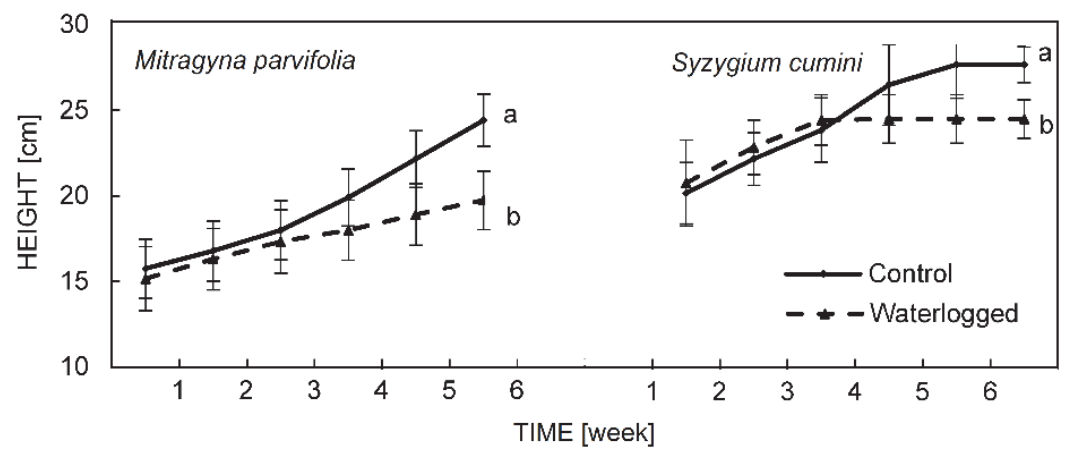

Fig. 1. Seedling height in response to waterlogging, where each value represents mean replicates \pm SE $(n=7)$. Treatments followed by different letters are statistically significant $(p \leq 0.05)$.

Table 2. Change in the seedling's leaf, stem, and root dry mass, and leaf area after 35 days of waterlogging. Data given are mean \pm SE $(n=4)$. Values followed by the same letters are not statistically significant at $\alpha=0.05$ after Student's $t$-test. MC - Mitragyna parvifolia control; MW - M. parvifolia waterlogged; SC - Syzygium cumini control; SW - S. cumini waterlogged.

\begin{tabular}{|c|c|c|c|c|}
\hline Parameter & $\mathrm{MC}$ & MW & $\mathrm{SC}$ & SW \\
\hline Leaf [g per plant] & $11.64 \pm 0.25^{\mathrm{a}}$ & $8.76 \pm 0.18^{b}$ & $4.51 \pm 0.39 \mathrm{a}$ & $3.36 \pm 0.26^{\mathrm{a}}$ \\
\hline Stem [g per plant] & $7.68 \pm 0.18^{\mathrm{a}}$ & $4.96 \pm 0.91^{\mathrm{a}}$ & $3.70 \pm 0.13 a$ & $0.96 \pm 0.02^{b}$ \\
\hline Root [g per plant] & $6.30 \pm 0.37^{\mathrm{a}}$ & $10.15 \pm 0.38^{b}$ & $2.93 \pm 0.23^{\mathrm{a}}$ & $1.56 \pm 0.07^{\mathrm{b}}$ \\
\hline Leaf area $\left[\mathrm{cm}^{2}\right.$ per lea & $68.75 \pm 2.46^{\mathrm{a}}$ & $43.25 \pm 2.80^{\mathrm{b}}$ & $35.50 \pm 3.32^{\mathrm{a}}$ & $30.00 \pm 1.77^{\mathrm{t}}$ \\
\hline
\end{tabular}


Table 3. Change in the macronutrients concentration in leaf, stem, and root of the seedlings after 35 days of waterlogging. Data given are mean \pm SE $(n=4)$. Values followed by different letters are statistically significant $(p \leq 0.05)$ after Student's $t$-test. MC - Mitragyna parvifolia control; MW - M. parvifolia waterlogged; SC - Syzygium cumini control; SW - S. cumini waterlogged.

\begin{tabular}{lccll}
\hline $\begin{array}{l}\text { Macronutrients } \\
{\left[\mathrm{mg} \mathrm{kg}^{-1}\right]}\end{array}$ & $\mathrm{MC}$ & $\mathrm{MW}$ & $\mathrm{SC}$ & $\mathrm{SW}$ \\
\hline $\mathrm{Leaf}$ & & & \\
$\mathrm{N}$ & & & & \\
$\mathrm{P}$ & $27.63 \pm 0.06^{\mathrm{a}}$ & $16.52 \pm 0.01^{\mathrm{b}}$ & $22.3 \pm 0.04^{\mathrm{a}}$ & $11.15 \pm 0.00^{\mathrm{b}}$ \\
$\mathrm{K}$ & $0.46 \pm 0.01^{\mathrm{a}}$ & $0.36 \pm 0.00^{\mathrm{b}}$ & $0.38 \pm 0.02^{\mathrm{a}}$ & $0.36 \pm 0.00^{\mathrm{b}}$ \\
$\mathrm{Mg}$ & $37.51 \pm 0.40^{\mathrm{a}}$ & $17.52 \pm 0.19^{\mathrm{b}}$ & $7.28 \pm 0.37^{\mathrm{a}}$ & $3.25 \pm 0.28^{\mathrm{b}}$ \\
$\mathrm{Ca}$ & $1.39 \pm 0.01^{\mathrm{a}}$ & $1.17 \pm 0.02^{\mathrm{b}}$ & $1.54 \pm 0.00^{\mathrm{a}}$ & $1.19 \pm 0.00^{\mathrm{b}}$ \\
$\mathrm{Stem}$ & $7.03 \pm 0.02^{\mathrm{a}}$ & $0.11 \pm 0.00^{\mathrm{b}}$ & $3.39 \pm 0.00^{\mathrm{a}}$ & $3.00 \pm 0.00^{\mathrm{b}}$ \\
$\mathrm{N}$ & & & & \\
$\mathrm{P}$ & & & & \\
$\mathrm{K}$ & $7.64 \pm 0.00^{\mathrm{a}}$ & $2.61 \pm 0.00^{\mathrm{b}}$ & $12.51 \pm 0.01^{\mathrm{a}}$ & $5.67 \pm 0.00^{\mathrm{b}}$ \\
$\mathrm{Mg}$ & $0.39 \pm 0.01^{\mathrm{a}}$ & $0.34 \pm 0.01^{\mathrm{b}}$ & $0.36 \pm 0.00^{\mathrm{a}}$ & $0.33 \pm 0.00^{\mathrm{b}}$ \\
$\mathrm{Ca}$ & $17.73 \pm 0.16^{\mathrm{a}}$ & $9.28 \pm 0.19^{\mathrm{b}}$ & $7.47 \pm 0.18^{\mathrm{a}}$ & $0.75 \pm 0.02^{\mathrm{b}}$ \\
$\mathrm{Root}$ & $1.18 \pm 0.00^{\mathrm{a}}$ & $2.88 \pm 0.03^{\mathrm{b}}$ & $1.74 \pm 0.01^{\mathrm{a}}$ & $1.42 \pm 0.00^{\mathrm{b}}$ \\
$\mathrm{N}$ & $2.08 \pm 0.00^{\mathrm{a}}$ & $5.30 \pm 0.00^{\mathrm{b}}$ & $2.32 \pm 0.01^{\mathrm{a}}$ & $1.22 \pm 0.00^{\mathrm{b}}$ \\
$\mathrm{P}$ & & & & \\
$\mathrm{K}$ & $11.55 \pm 0.01^{\mathrm{a}}$ & $11.21 \pm 0.02^{\mathrm{b}}$ & $9.86 \pm 0.01^{\mathrm{a}}$ & $12.36 \pm 0.00^{\mathrm{b}}$ \\
$\mathrm{Mg}$ & $0.38 \pm 0.02^{\mathrm{a}}$ & $0.35 \pm 0.00^{\mathrm{b}}$ & $0.36 \pm 0.00^{\mathrm{a}}$ & $0.30 \pm 0.00^{\mathrm{b}}$ \\
$\mathrm{Ca}$ & $15.05 \pm 0.07^{\mathrm{a}}$ & $13.31 \pm 0.11^{\mathrm{b}}$ & $4.69 \pm 0.20^{\mathrm{a}}$ & $2.05 \pm 0.03^{\mathrm{b}}$ \\
\hline
\end{tabular}

Table 4. Change in the micronutrients concentration in leaf, stem and root of the seedlings after 35 days of waterlogging. Data given are mean \pm SE $(n=4)$. Values followed by different letters are statistically significant $(p \leq 0.05)$ after Student's $t$-test. MC - Mitragyna parvifolia control; MW - M. parvifolia waterlogged; SC - Syzygium cumini control; SW - S. cumini waterlogged.

\begin{tabular}{|c|c|c|c|c|}
\hline $\begin{array}{l}\text { Micronutrients } \\
{\left[\mathrm{mg} \mathrm{kg}^{-1}\right]}\end{array}$ & $\mathrm{MC}$ & MW & $\mathrm{SC}$ & SW \\
\hline \multicolumn{5}{|l|}{ Leaf } \\
\hline $\mathrm{Na}$ & $7.92 \pm 0.14^{\mathrm{a}}$ & $4.54 \pm 0.17^{b}$ & $17.05 \pm 0.07^{\mathrm{a}}$ & $10.3 \pm 0.31^{\mathrm{b}}$ \\
\hline $\mathrm{Co}$ & $0.13 \pm 0.00^{\mathrm{a}}$ & $0.14 \pm 0.00^{\mathrm{b}}$ & $0.16 \pm 0.00^{\mathrm{a}}$ & $0.07 \pm 0.01^{\mathrm{b}}$ \\
\hline $\mathrm{Cr}$ & $0.25 \pm 0.00^{\mathrm{a}}$ & $0.24 \pm 0.10^{\mathrm{b}}$ & $0.73 \pm 0.01^{\mathrm{a}}$ & $0.23 \pm 0.06^{\mathrm{b}}$ \\
\hline $\mathrm{Cu}$ & $0.06 \pm 0.00^{\mathrm{a}}$ & $0.06 \pm 0.00^{\mathrm{b}}$ & $0.03 \pm 0.00^{\mathrm{a}}$ & $0.14 \pm 0.01^{\mathrm{b}}$ \\
\hline $\mathrm{Zn}$ & $0.01 \pm 0.01^{\mathrm{a}}$ & $0.01 \pm 0.01^{\mathrm{b}}$ & $0.01 \pm 0.00^{\mathrm{a}}$ & $0.02 \pm 0.02^{\mathrm{b}}$ \\
\hline $\mathrm{Fe}$ & $1.37 \pm 0.01^{\mathrm{a}}$ & $3.48 \pm 0.00^{\mathrm{b}}$ & $0.40 \pm 0.00^{\mathrm{a}}$ & $0.97 \pm 0.00^{\mathrm{b}}$ \\
\hline $\mathrm{Mn}$ & $0.48 \pm 0.01^{\mathrm{a}}$ & $0.07 \pm 0.00^{\mathrm{b}}$ & $0.05 \pm 0.00^{\mathrm{a}}$ & $0.08 \pm 0.00^{\mathrm{b}}$ \\
\hline \multicolumn{5}{|l|}{ Stem } \\
\hline $\mathrm{Na}$ & $5.13 \pm 0.09^{\mathrm{a}}$ & $7.31 \pm 0.13^{\mathrm{a}}$ & $13.05 \pm 0.69^{a}$ & $9.55 \pm 0.03^{b}$ \\
\hline $\mathrm{Co}$ & $0.10 \pm 0.00^{\mathrm{a}}$ & $0.14 \pm 0.00^{\mathrm{b}}$ & $0.09 \pm 0.00^{\mathrm{a}}$ & $0.05 \pm 0.01^{\mathrm{b}}$ \\
\hline $\mathrm{Cr}$ & $0.09 \pm 0.00^{\mathrm{a}}$ & $0.49 \pm 0.03^{b}$ & $0.23 \pm 0.00^{\mathrm{a}}$ & $0.16 \pm 0.13^{b}$ \\
\hline $\mathrm{Cu}$ & $0.04 \pm 0.00^{\mathrm{a}}$ & $0.09 \pm 0.03^{\mathrm{a}}$ & $0.02 \pm 0.00^{\mathrm{a}}$ & $0.10 \pm 0.02^{b}$ \\
\hline $\mathrm{Zn}$ & $0.01 \pm 0.01^{\mathrm{a}}$ & $0.01 \pm 0.03^{\mathrm{a}}$ & $0.01 \pm 0.00^{\mathrm{a}}$ & $0.01 \pm 0.012^{b}$ \\
\hline $\mathrm{Fe}$ & $2.05 \pm 0.01^{\mathrm{a}}$ & $1.30 \pm 0.03^{b}$ & $0.36 \pm 0.00^{\mathrm{a}}$ & $2.43 \pm 0.00^{\mathrm{b}}$ \\
\hline $\mathrm{Mn}$ & $0.07 \pm 0.00^{\mathrm{a}}$ & $0.01 \pm 0.00^{\mathrm{b}}$ & $0.31 \pm 0.00^{\mathrm{a}}$ & $0.08 \pm 0.00^{\mathrm{b}}$ \\
\hline \multicolumn{5}{|l|}{ Root } \\
\hline $\mathrm{Na}$ & $4.95 \pm 0.11^{\mathrm{a}}$ & $10.42 \pm 0.14^{b}$ & $14.78 \pm 0.26^{\mathrm{a}}$ & $9.87 \pm 0.35^{\mathrm{b}}$ \\
\hline $\mathrm{Co}$ & $0.15 \pm 0.00^{\mathrm{a}}$ & $0.12 \pm 0.00^{\mathrm{b}}$ & $0.34 \pm 0.18^{\mathrm{a}}$ & $0.09 \pm 0.00^{\mathrm{b}}$ \\
\hline $\mathrm{Cr}$ & $0.40 \pm 0.00^{\mathrm{a}}$ & $0.30 \pm 0.06^{\mathrm{a}}$ & $0.12 \pm 0.00^{\mathrm{a}}$ & $0.48 \pm 0.051$ \\
\hline $\mathrm{Cu}$ & $0.04 \pm 0.00^{\mathrm{a}}$ & $0.16 \pm 0.02^{\mathrm{b}}$ & $0.02 \pm 0.00^{\mathrm{a}}$ & $0.06 \pm 0.03^{\mathrm{b}}$ \\
\hline $\mathrm{Zn}$ & $0.02 \pm 0.00^{\mathrm{a}}$ & $0.02 \pm 0.12^{\mathrm{a}}$ & $0.09 \pm 0.00^{\mathrm{a}}$ & $0.01 \pm 0.03^{\mathrm{a}}$ \\
\hline $\mathrm{Fe}$ & $1.13 \pm 0.00^{\mathrm{a}}$ & $0.45 \pm 0.03^{b}$ & $0.55 \pm 0.00^{\mathrm{a}}$ & $0.38 \pm 0.00^{\mathrm{b}}$ \\
\hline $\mathrm{Mn}$ & $0.02 \pm 0.00^{\mathrm{a}}$ & $0.07 \pm 0.00^{\mathrm{b}}$ & $0.62 \pm 0.00^{\mathrm{a}}$ & $0.18 \pm 0.00^{\mathrm{b}}$ \\
\hline
\end{tabular}


Chl concentration: After $35 \mathrm{~d}$ of waterlogging, as compared with the controls, significant decreases in the concentrations of total $\mathrm{Chl}, \mathrm{Chl} a$, and $\mathrm{Chl} b$ were observed in both species (Fig. 2).

Gas exchange and Chl fluorescence: Waterlogging significantly affected the gas exchange variables (Fig. 3). In $M$. parvifolia, $P_{\mathrm{N}}$ declined by approximately $75 \%$, whereas $g_{\mathrm{s}}, E$, and WUE declined by $47.5,45.1$, and $60 \%$,

\section{Discussion}

Plant survival and growth: The results from our study suggest that seedlings of $M$. parvifolia were relatively more tolerant to waterlogging than those of S. cumini. Seedling survival was $10 \%$ in S. cumini in contrast to $100 \%$ in M. parvifolia after $35 \mathrm{~d}$ of the experiment. High mortality in S. cumini seedlings suggests its failure to combat flood-related injuries resulting from anaerobic conditions in the root systems, which reduces the energy yield of carbohydrates and increases the production of toxic compounds such as ethanol or lactate (Schaffer et al. 1992, Joly and Brandle 1995). Yellowing of leaves was observed in both species under waterlogged conditions, which is a common visual symptom under waterlogging (Smethurst et al. 2003). However, M. parvifolia seedlings displayed the necessary adaptive traits such as (1) the formation of adventitious roots which oxidize the rhizosphere, thereby converting soil-borne toxins into less harmful compounds and supporting shoot growth by providing water, minerals, and hormones (Kozlowski 1997) and (2) the formation of lenticels that act as a pathway for gas exchange (Kozlowski and Pallardy 2002). The phytohormone auxin is generally responsible for the formation of adventitious roots during flooding (Lambers et al. 2008). Various researchers have observed a reduction in height in many species, such as Platanus occident (Tang and Kozlowski 1982) and Pterocarya stenoptera (Li et al. 2010). In contrast, Yamamoto et al. (1995) in Fraxinus mandshurica and Parolin et al. (2001) in an Amazon floodplain tree species found that height was not severely affected by waterlogging. A significant decline in height was observed for both species (Fig. 1), which can be explained by a low oxygen supply to the root system, a decrease in the capacity of plants to absorb water and respectively (Table 1, Fig. 3A-D). Similarly, in S. cumini, $P_{\mathrm{N}}$ and $g_{\mathrm{s}}$ declined significantly by 93.9 and $58.2 \%$, respectively, whereas $E$ and WUE increased by 6 and $60 \%$, respectively (Table 1, Fig. $3 A-D$ ). The trends of these variables fluctuated in both species. The values of $F_{v} / F_{m}$ decreased in both species as compared with the controls; however, the decline was significant only in the case of $S$. cumini after $35 \mathrm{~d}$ of waterlogging (Fig. $3 E$ ).

nutrients, and a decline in synthesizing hormones such as cytokinins (Jackson 1993, Oliveira et al. 2010). The reduction in growth also depends on the depth of water above the soil surface (Malik et al. 2001). Flooding is reported to suppress leaf formation and expansion, and causes premature leaf senescence and abscission in plants (Kozlowski 1997). A significant reduction in LA was observed in both species (Table 2). However, this decrease can be explained by the reduction in carbon uptake in the seedlings, as reported in Jatropha curcas (Verma et al. 2012) and Genipa americana (Mielke et al. 2003).

Plant biomass: Decreases in dry mass as compared with those in controls were observed in many species under the flooding treatment. It has been also reported that fungal infection causes root decay in flood-sensitive species (Stolzy and Sojka 1984). Reductions in biomass were observed in both species, except for the root biomass in M. parvifolia, which showed a significant increase (Table 1). Seedlings of $S$. cumini showed root rot and died after $35 \mathrm{~d}$ of waterlogging, which can be linked to the significant reduction in root biomass $(60.9 \%)$ and reflects the disability of $S$. cumini seedlings to adapt to waterlogging. The observed decrease in biomass was related to slow metabolic activity under anoxia, which impairs mitochondrial electron transport, glycolysis, and oxidation of NADP, $\mathrm{H}^{+}$, and ATP synthesis, and leads to the production of acetaldehyde, ethanol, and lactic acid (Pezeshki 1994, Drew 1997, Gibbs and Greenway 2003, Mielke et al. 2005). The increase in root biomass in M. parvifolia was partly a result of the formation of adventitious roots, as observed in Muehlenbeckia florulenta by Capon et al. (2009). Despite lower height,

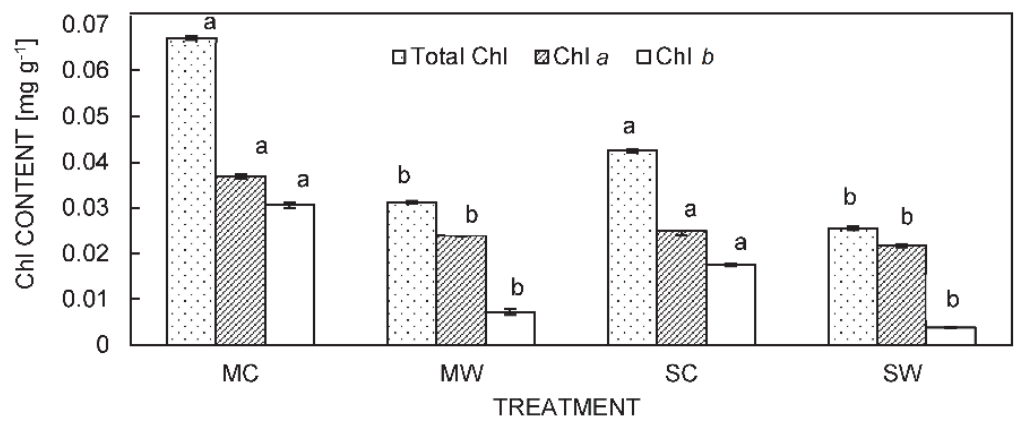

712
Fig. 2. Leaf chlorophyll (Chl) $a, b$ and total $\mathrm{Chl}$ in response to waterlogging where each value represents mean replicates $\pm \mathrm{SE}(n=4)$. Treatments followed by different letters are statistically significant $(p \leq 0.05)$. MC - Mitragyna parvifolia control; MW - M. parvifolia waterlogged; SC - Syzygium cumini control; $\mathrm{SW}-\mathrm{S}$. cumini waterlogged. 


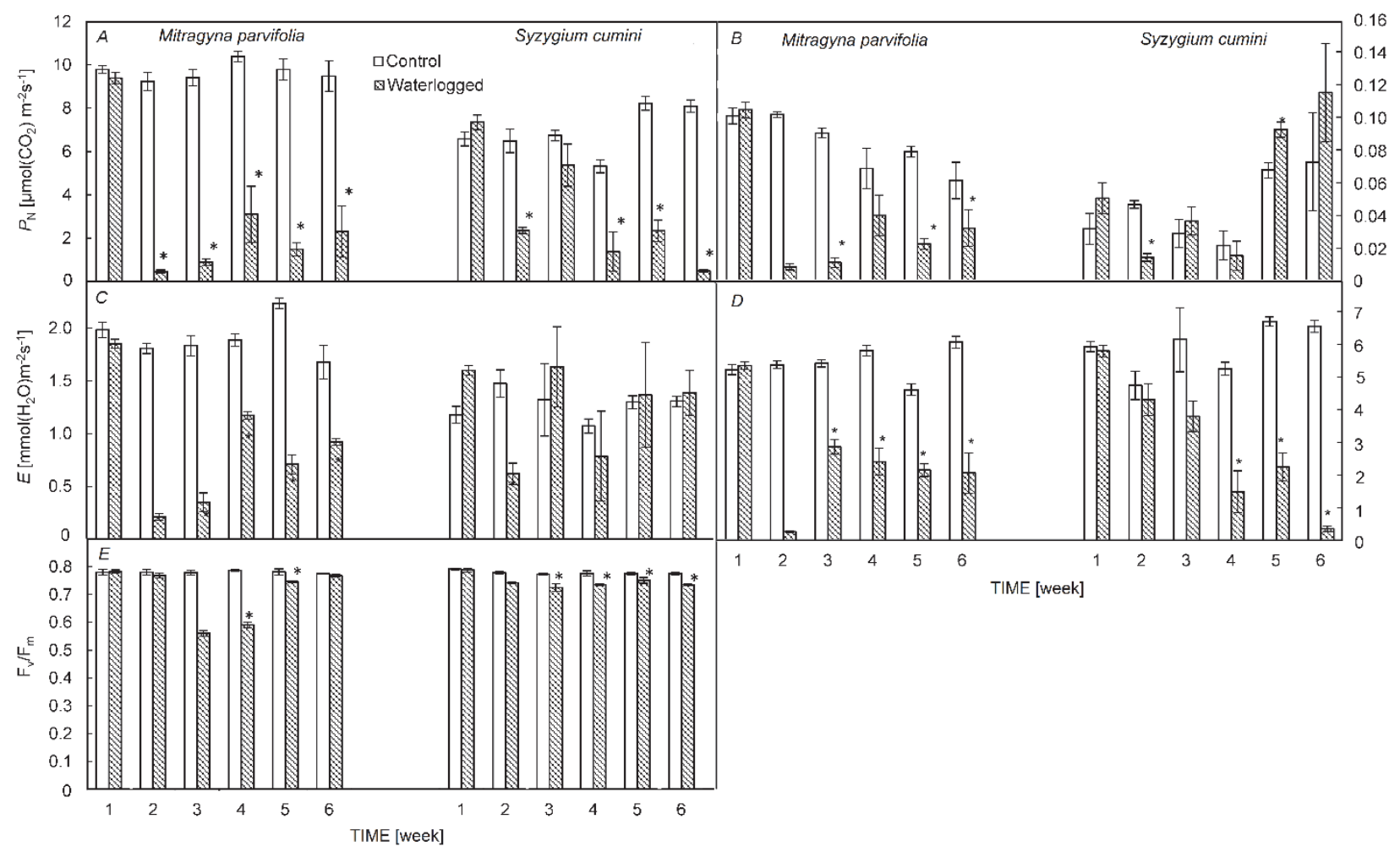

Fig. 3: Effect of waterlogging on the net photosynthetic rate $\left(P_{\mathrm{N}} ; A\right)$, stomatal conductance $\left(g_{\mathrm{s}} ; B\right)$, transpiration rate $(E ; C)$, water-use efficiency (WUE; $D$ ), and $\mathrm{F}_{\mathrm{v}} / \mathrm{F}_{\mathrm{m}}(E)$ during 35 days. Each value represents the mean $\pm \mathrm{SE}(n=4)$. Treatments followed by different letters are statistically significant $(p \leq 0.05)$.

M. parvifolia showed higher biomass than that of S. cumini, reflecting the carbon investment in leaf, stem, and root biomass by the plant rather than an increase in height.

Plant mineral nutrient concentrations: Nutrients play an essential role in plant growth and development (Perkins et al. 2011). The concentrations of $\mathrm{N}, \mathrm{P}$, and $\mathrm{K}$ have been found to be reduced under waterlogging (Kozlowski 1997). Similar results were observed in the current study for both $S$. cumini and $M$. parvifolia seedlings, except for $\mathrm{P}$ and $\mathrm{N}$ of the leaves and roots (Table 3). Flooding disrupts the mineral composition of plants because soil aeration influences the mineral absorption by the roots (Yang et al. 2013). At the same time, the absorption of mineral elements is accomplished through active transport, which is closely related to the generation of ATP from respiration in plant roots (Huang et al. 2007). The lowering of nutrient status in plants may trigger the formation of cluster roots on lateral adventitious roots in some plant species, e.g., Hakea (Poot and Lambers 2003). The formation of adventitious roots in M. parvifolia can be associated with an imbalance in mineral status. A study by Chen et al. (2005) on Lepidium latifolium found that the concentrations of $\mathrm{N}, \mathrm{P}, \mathrm{K}$, and $\mathrm{Zn}$ decreased, $\mathrm{Mn}$ and $\mathrm{Fe}$ increased, and $\mathrm{P}, \mathrm{N}, \mathrm{K}$, and $\mathrm{Zn}$ were higher in roots. In contrast, Gimeno et al. (2012) observed an increase in leaf
$\mathrm{Ca}, \mathrm{Mg}$, and $\mathrm{P}$ in Jatropha curcas. The increase of $\mathrm{Na}^{+}$ concentration in the roots of $S$. cumini reflects a decrease in the selectivity of $\mathrm{K}^{+} / \mathrm{Na}^{+}$uptake by roots in favor of $\mathrm{Na}^{+}$ and retards the transport of $\mathrm{K}^{+}$to the shoots (Thomson et al. 1989). Such ion selectivity was also observed in L. latifolium (Chen et al. 2005).

Chl concentrations under waterlogging: Leaf chlorosis is commonly observed in plants under stress, and is a condition that leads to senescence and is associated with a concomitant decline in the concentration of photosynthetic pigments (Webb and Fletcher 1996). A reduction in Chl contents in leaves is common under flooding/waterlogged conditions (Webb and Fletcher 1996, Yordanova and Popova 2001). In our experiment, the contents of total Chl, $\mathrm{Chl} a$, and Chl $b$ significantly decreased in both species under waterlogged conditions (Fig. 2), thereby confirming the results of previous studies in other plants, such as Arachis hypogaea (Bishnoi and Krishnamoorthy 1992), Ricinus communis (Gadallah 1995), white and red clover (Simova-Stoilova et al. 2012), and Pyrus persica (Insausti and Gorjón 2013). Such a decrease is considered as a protection mechanism employed within photosynthetic structures, which reduces sunlight absorption and avoids photo-oxidation, as explained by $\mathrm{Du}$ et al. (2012) in Populus simonii and P. lux. Chl $b$ is reported to be more sensitive to flooding than Chl $a$ (Ashraf and Arfan 2005), 
and we observed a larger decrease in Chl $b$ than that in $\mathrm{Chl} a$. However, since $\mathrm{Chl} b$ is an accessory pigment of the LHC, its decline can result in reduced photochemical efficiency as well as photoinhibition. However, under waterlogging, a decline in $\mathrm{Chl} b$ may have a significant effect on LHCII complexes containing $\mathrm{Chl} b$ in the mature thylakoid membranes (Green 1988, Sairam et al. 2009).

Leaf gas exchange and Chl $a$ fluorescence under waterlogging: Reductions in gas exchange in both species confirmed the results of previous studies of many floodtolerant and flood-intolerant species. Stomatal limitations are considered to be the initial cause of a decrease in photosynthesis during flooding (Pezeshki 1993, Kozlowski 1997). However, during a longer period of flooding, nonstomatal limitations occur, such as pigment degradation and alteration of enzymes in the Calvin Cycle, which lead to a decline in carboxylation efficiency (Pezeshki 2001). In addition, feedback inhibition by starch accumulation in leaves due to lack of transport by roots was observed in watermelon (Yetisir et al. 2006). The significant decline in $P_{\mathrm{N}}$ and $g_{\mathrm{s}}$ observed in M. parvifolia (Fig. 3) can be explained by stomatal closure due to hypoxia, which limits $P_{\mathrm{N}}$. Similar results were obtained in Momordica charantia (Liao and Lin 1994) and certain herbaceous species (Jackson and Drew 1984). The recovery of $P_{\mathrm{N}}$ is related to the formation of adventitious roots and lenticels, which are further linked to the reopening of stomata that had closed shortly after the flooding was initiated (Gomes and Kozlowski 1980). However, S. cumini seedlings showed high fluctuations in gas exchange while still alive (Fig. 3). The stomatal closure may be related to a decrease in root hydraulic conductivity (Andersen et al. 1984, Davies and Flore 1986), which is a common response observed in both tolerant and intolerant woody plants under flooding (Kozlowski 1997, Bertolde et al. 2010). Newsome et al. (1982) observed that flooding did not induce stomatal closure in Ulmus americana seedlings. Liu and Dickman (1992) observed stomatal closing after $9 \mathrm{~d}$ in hybrid Populus clones. Quercus macrocarpa seedlings failed to reopen stomata (Tang and Kozlowski 1982), whereas Harrington (1987) observed no stomatal closing in $P$. trichocarpa. In our study, the $E$ was correlated with $g_{\text {s }}$ in both species (Fig. 3B,C). This trend is also commonly observed in other species such as Melaleuca alternifolia (Jing et al. 2009). Greater WUE is commonly observed in plants under flooding conditions (Bertolde 2012). In our study, we did not identify any increase in WUE in both species, which supports the results of Mielke et al. (2003) in their study on Genipa americana, the results of Arbona et al. (2009) in citrus, and those of Islam (2004) in tamarack; however, our results were not supported by the findings of Islam (2004) in a study on black spruce.

The leaf Chl $a$ fluorescence or the ratio of $\mathrm{F}_{\mathrm{v}} / \mathrm{F}_{\mathrm{m}}$ is considered to be an important indicator of the effects of environmental stresses and the status of PSII machinery
(Maxwell and Johnson 2000, Kalaji et al. 2016). This is a widely used technique because of its rapid and noninvasive nature, and provides detailed information on the state of PSII (Papageorgiou and Govindjee 2011, Murchie and Lawson 2013). A decrease in the value of $F_{v} / F_{m}$ is a good indicator of photoinhibitory impairment resulting from waterlogging stress (Mielke et al. 2003, Bertolde et al. 2010). In our experiment, the values of $F_{v} / F_{m}$ declined significantly in S. cumini seedlings, possibly reflecting photodamage in S. cumini, as observed in Myrica cerifera (Naumann et al. 2008) under flooding. The values of $\mathrm{F}_{\mathrm{v}} / \mathrm{F}_{\mathrm{m}}$ of $M$. parvifolia seedlings showed no significant decrease during the experimental period, except at 21 and $28 \mathrm{~d}$, then it recovered (Fig. $3 D$ ). However, $\mathrm{F}_{\mathrm{v}} / \mathrm{F}_{\mathrm{m}}$ values were within the range for healthy plants (Percival et al. 2003). Similar results were obtained by Meilke et al. (2003) in Genipa americana, which indicated no photodamage.

Conclusion: Based on our results, we rejected our hypothesis that both M.parvifolia and S.cumini are adapted to waterlogging because they inhabit a wetland. S. cumini seedlings were highly susceptible to waterlogging because this species lacks adaptive traits required to survive under flooding conditions, ultimately leading to impairment of gas exchange, nutrient imbalance, decreased growth, chlorophyll loss with yellowing of the leaves. In contrast, $M$. parvifolia seedlings survived waterlogged conditions. In addition, $\mathrm{Chl} b$ was more sensitive to waterlogging than Chl $a$ in both species. However, the performance of $M$. parvifolia seedlings also declined under waterlogging, although gas exchange recovered after the development of adventitious roots and lenticels. The tolerance of $M$. parvifolia to flooding may increase survival of its seedlings in comparison to S. cumini seedlings in waterlogged areas in the KNP. Prolonged water scarcity in the KNP allowed other species to establish themselves in the forest along with established species. The survival and establishment of the species depends on the prevailing biotic and abiotic environmental conditions at the particular time. The presented results can be considered as a baseline study for designing field-based experiments. The results of the present study provided insight into waterlogging tolerance in both species; however, results are difficult to predict under field conditions because other factors, such as plant age, depth, and duration of flooding, soil conditions, and the presence of monsoon also determine seedling survival. However, understanding the physical tolerances of M. parvifolia and $S$. cumini can assist land managers and policy planners in the formulation of strategies for restoration, plantation, and protection of the species across regions with similar environmental conditions. Furthermore, flood tolerance is an important trait for species survival in a wetland; however, rapid changes in environmental conditions can alter the future composition of vegetation within an ecosystem. 


\section{References}

Allen S.E.: Analysis of vegetation and other organic materials. In: Allen S.E., Davison W., Grimshaw H.M. et al. (ed.): Chemical Analysis of Ecological Materials. Pp. 46-60. Blackwell Sci. Publ., Oxford 1974.

Andersen P.C., Lombard P.B., Westwood M.N.: Leaf conductance, growth, and survival of willow and deciduous fruit tree species under flooded soil conditions. - J. Am. Soc. Hortic. Sci. 109: 132-138, 1984.

Arbona V., López-Climent M.F., Pérez-Clemente R.M. et al.: Maintenance of a high photosynthetic performance is linked to flooding tolerance in citrus. - Environ. Exp. Bot. 66: 135-142, 2009.

Armstrong W., Brändle R., Jackson M.B.: Mechanisms of flood tolerance in plants. - Acta. Bot. Neerl. 43: 307-358, 1994.

Arnell N.W.: Climate change and global water resources. - Glob. Environ. Chang. 9: S31-S49, 1999.

Arnon D.I.: Copper enzymes in isolated chloroplasts. Polyphenoloxidase in Beta vulgaris. - Plant Physiol. 24: 1-15, 1949.

Ashraf M., Arfan M.: Gas exchange characteristics and water relations in two cultivars of Hibiscus esculentus under waterlogging. - Biol. Plantarum 49: 459-462, 2005.

Ashraf M.A.: Waterlogging stress in plants: A review. - Afr. J. Agric. Res. 7: 1976-1981, 2012.

Bąba W., Kalaji H.M., Kompała-Bąba A. et al.: Acclimatization of photosynthetic apparatus of tor grass (Brachypodium pinnatum) during expansion. - PLoS ONE, 11: e0156201, 2016.

Bailey-Serres J., Voesenek L.A.C.J.: Flooding stress: acclimations and genetic diversity. - Annu. Rev. Plant. Biol. 59: 313339, 2008.

Banach K., Banach A.M., Lamers L.P. et al.: Differences in flooding tolerance between species from two wetland habitats with contrasting hydrology: implications for vegetation development in future floodwater retention areas. - Ann. Bot.London 103: 341-351, 2009.

Bassi N., Kumar M.D., Sharma A. et al.: Status of wetlands in India: A review of extent, ecosystem benefits, threats and management strategies. - J. Hydrol. Reg. Stud. 2: 1-19, 2014.

Bertolde F.Z., Almeida A.A.F., Pirovani C.P. et al.: Physiological and biochemical responses of Theobroma cacao L. genotypes to flooding. - Photosynthetica 50: 447-457, 2012.

Bertolde F.Z., Almeida A.A.F., Corrêa R.X. et al.: Molecular, physiological and morphological analysis of water-logging tolerance in clonal genotypes of Theobroma cacao L. - Tree Physiol. 30: 56-67, 2010.

Bidalia A., Hanief M., Rao K.S.: Tolerance of Mitragyna parvifolia (Roxb.) Korth. seedlings to $\mathrm{NaCl}$ salinity. Photosynthetica 55: 231-239, 2016.

Bishnoi N.R., Krishnamoorthy H.N.: Effect of waterlogging and gibberellic acid on leaf gas exchange in peanut (Arachis hypogaea L.). - J. Plant Physiol. 139: 503-505, 1992.

Blom C.W.P.M., Voesenek L.A.C.J.: Flooding: The survival strategies of plants. - Trends Ecol. Evol. 11: 290-295, 1996.

Brar A.S.: Case study 4: India-Keoladeo National Park. - In: Hali A.J. (ed.): Wetlands, Biodiversity and the Ramsar Convention, Ramsar. Pp. 68-70. Ramsar Convention Bureau, Gland 1996.

Capon S.J., James C.S., Williams L. et al.: Responses to flooding and drying in seedlings of a common Australian desert floodplain shrub: Muehlenbeckia florulenta Meisn. (Tangled lignum). - Environ. Exp. Bot. 66: 178-185, 2009.

Chauhan M., Gopal B.: Biodiversity and management of Keoladeo National Park (India) - a wetland of international importance. - In: Gopal B., Junk W.J., Davis J.A. (ed.): Biodiversity in Wetlands: Assessment, Function and Conservation. Pp. 217-256. Backhuys Publishers, Leiden 2001.

Chen H., Qualls R.G., Blank R.R.: Effect of soil flooding on photosynthesis, carbohydrate partitioning and nutrient uptake in the invasive exotic Lepidium latifolium. - Aquat. Bot. 82: 250-268, 2005.

Colmer T.D., Voesenek L.A.C.J.: Flooding tolerance: suites of plant traits in variable environments. - Funct. Plant Biol. 36: 665-681, 2009

Cooke S.J., O'Connor C.M.O.: Making conservation physiology relevant to policy makers and conservation practitioners. Conserv. Biol. 3: 159-166, 2010.

Dąbrowski P., Baczewska A.H., Pawluśkiewicz B. et al.: Prompt chlorophyll a fluorescence as a rapid tool for diagnostic changes in PSII structure inhibited by salt stress in Perennial ryegrass. - J. Photoch. Photobio. B. 157: 22-31, 2016.

Dąbrowski P., Kalaji M.H., Baczewska, A.H. et al.: Delayed chlorophyll $a$ fluorescence, MR 820, and gas exchange changes in perennial ryegrass under salt stress. - J. Lumin. 183: 322 333, 2017.

Dąbrowski P., Pawluśkiewicz B. Baczewska A.H. et al: Chlorophyll $a$ fluorescence of perennial ryegrass (Lolium perenne L.) varieties under long term exposure to shade. Zemdirbyste. 3: 305-312, 2015.

Davies F.S., Flore J.A.: Flooding, gas exchange and hydraulic conductivity of highbush blueberry. - Physiol. Plantarum 67: 545-551, 1986

Drew M.C.: Oxygen deficiency and root metabolism: injury and acclimation under hypoxia and anoxia. - Annu. Rev. Plant Phys. 48: 223-250, 1997.

Du K., Xu L., Wu H. et al.: Ecophysiological and morphological adaption to soil flooding of two poplar clones differing in flood-tolerance. - Flora 207: 96-106, 2012.

Erwin K.L.: Wetlands and global climate change: the role of wetland restoration in a changing world. - Wetl. Ecol. Manag. 17: 71-84, 2009.

Ewing K.: Tolerance of four wetland plant species to flooding and sediment deposition. - Environ. Exp. Bot. 36: 131-146, 1996.

Gadallah M.A.A. Effect of waterlogging and kinetin on the stability of leaf membranes, leaf osmotic potential, soluble carbon and nitrogen compounds and chlorophyll content of Ricinus plants. - Phyton 35: 199-208, 1995.

Gibbs J., Greenway H.: Review: Mechanisms of anoxia tolerance in plants. I. Growth, survival and anaerobic catabolism. Funct. Plant Biol. 30: 1-47, 2003.

Gimeno V., Syvertsen J.P., Simón I. et al.: Physiological and morphological responses to flooding with fresh or saline water in Jatropha curcas. - Environ. Exp. Bot. 78: 47-55, 2012.

Goltsev V.N., Kalaji, H.M., Paunov, M. et al.: Variable chlorophyll fluorescence and its use for assessing physiological condition of plant photosynthetic apparatus. - Russ. J. Plant Physl+ 63: 869-893, 2016

Gomes A.S., Kozlowski T.T.: Responses of Melaleuca quinquenervia seedlings to flooding. - Physiol. Plantarum 49: 373-377, 1980

Gopal B.: Future of wetlands in tropical and subtropical Asia, especially in the face of climate change. - Aquat. Sci. 75: 3961,2013

Govindjee: Chlorophyll $a$ fluorescence: a bit of basics and 
history. - In: Papageorgiou G.C., Govindjee (ed.): Chlorophyll a Fluorescence: A Signature of Photosynthesis. Pp. 2-42. Springer, Dordrecht 2004.

Green B.R.: The chlorophyll-protein complexes of higher plant photosynthetic membranes. - Photosynth. Res. 15: 3-32, 1988.

Grimshaw H M., Allen S.E., Parkinson J.A.: Nutrient elements. - In: Allen S.E., Davison W., Grimshaw H.M. et al. (ed.): Chemical Analysis of Ecological Materials. Pp. 81-159. Blackwell Sci. Publ., Oxford 1974.

Harrington C.A.: Responses of red alder and black cottonwood seedlings to flooding. - Physiol. Plantarum 69: 35-48, 1987.

Hiscox J.D., Israelstam G.F.: A method for the extraction of chlorophyll from leaf tissue without maceration. - Can. J. Bot. 57: 1332-1334, 1979.

Hiwale S.: Jamun (Syzygium cuminii). - In: Hiwale S. (ed.): Sustainable Horticulture in Semiarid Dry Lands. Pp. 237-246. Springer, New Delhi 2015.

Huang M.L., Deng X.P., Zhao Y.Z. et al.: Water and nutrient use efficiency in diploid, tetraploid and hexaploid wheats. - J. Integr. Plant Biol. 49: 706-715, 2007.

Insausti P., Gorjón S.: Floods affect physiological and growth variables of peach trees (Prunus persica (L.) Batsch), as well as the postharvest behavior of fruits. - Sci. Hortic. 152: 56-60, 2013.

Islam M.A., Macdonald S.E.: Ecophysiological adaptations of black spruce (Picea mariana) and tamarack (Larix laricina) seedlings to flooding. - Trees 18: 35-42, 2004.

Jackson M.B., Drew M.C.: Effects of flooding on growth and metabolism of herbaceous plants. - In: Kozlowski T (ed.): Flooding and Plant Growth. Pp. 47-128. Academic Press, New York 1984.

Jackson M.B.: Are plant hormones involved in root to shoot communication? - Adv. Bot. Res. 19: 103-187, 1993.

Janeczko A., Gruszka D., Pociecha E. et al.: Physiological and biochemical characterisation of watered and drought-stressed barley mutants in the HvDWARF gene encoding C6-oxidase involved in brassinosteroid biosynthesis. - Plant Physiol. Bioch. 99: 126-141, 2016.

Jing Y.X., Li G.L., Gu B.H. et al.: Leaf gas exchange, chlorophyll fluorescence and growth responses of Melaleuca alternifolia seedlings to flooding and subsequent recovery. Photosynthetica 47: 595-601, 2009.

Joly C.A., Brandle R.: Fermentation and adenylate metabolism of Hedychium oronarium JG Koenig (Zingiberaceae) and Acorus calamus L.(Araceae) under hypoxia and anoxia. Funct. Ecol. 9: 505-510, 1995.

Kalaji H.M., Jajoo A., Oukarroum A. et al:: Chlorophyll a fluorescence as a tool to monitor physiological status of plants under abiotic stress conditions. - Acta Physiol. Plant. 38: 102113, 2016.

Kalaji H.M., Schansker G., Ladle R.J. et al.: Frequently asked questions about in vivo chlorophyll fluorescence: practical issues. - Photosyn. Res. 122: 121-158, 2014.

Kentula M.E.: Perspectives on setting success criteria for wetland restoration. - Ecol. Eng. 15: 199-209, 2000.

Kozlowski T., Pallardy S.: Acclimation and adaptive responses of woody plants to environmental stresses. - Bot. Rev. 68: 270334, 2002.

Kozlowski T.T., Pallardy S.G.: Effect of flooding on water, carbohydrate, and mineral relations. - In: Kozlowski T.T. (ed.): Flooding and Plant Growth. Pp. 165-193. Academic Press, Orlando 1984.

Kozlowski T.T.: Plant responses to flooding of soil. - Bioscience
34: 162-167, 1984

Kozlowski T.T.: Responses of woody plants to flooding and salinity. - Tree Physiol. Monogr. 1: 1-29, 1997.

Lambers H.F., Chapin III S., Thijs L.P.: Photosynthesis, respiration and long-distance transport. - In: Lambers H.F., Chapin III S., Thijs L.P (ed.): Plant Physiological Ecology. Pp. 11-99. Springer, New York 2008.

Li C.X., Wei H., Geng Y.H. et al.: Effects of submergence on photosynthesis and growth of Pterocarya stenoptera (Chinese wingnut) seedlings in the recently-created Three Gorges Reservoir region of China. - Wetl. Ecol. Manage. 18: 485-494, 2010.

Liao C.T., Lin C.H.: Effect of flooding stress on photosynthetic activities of Momordica charantia. - Plant Physiol. Bioch. 32: 479-485, 1994

Liu Z., Dickmann D.I.: Responses of two hybrid poplar clones to flooding, drought, and nitrogen availability. I. Morphology and growth. - Can. J. Bot. 70: 2265-2270, 1992.

Long S.P., Bernacchi C.J.: Gas exchange measurements, what can they tell us about the underlying limitations to photosynthesis? Procedures and sources of error. - J. Exp. Bot. 54: 2393-2401, 2003.

Malik A.I., Colmer T.D., Lambers H. et al.: Changes in physiological and morphological traits of roots and shoots of wheat in response to different depths of waterlogging. - Funct. Plant Biol. 28: 1121-1131, 2001.

Mathur V.B., Choudhury B.C., Sinha P.R. et al.: Ecological Monitoring in Keoldeo National Park and its Environs for Enhancing Management Effectiveness. Technical Report. 10. Pp. 1-10. United Nations Foundations, http://whc.unesco.org/ uploads/activities/documents/activity-331-17.pdf, 2010.

Maxwell K., Johnson G.N.: Chlorophyll fluorescence - a practical guide. - J. Exp. Bot. 51: 659-668, 2000.

Middleton B.A.: The flood pulse concept in wetland restoration. - In: Middleton B.A. (ed.): Flood Pulsing in Wetlands: Restoring the Natural Hydrological Balance. Pp. 1-10. John Wiley \& Sons, New York 2002.

Middleton B.A.: Vegetation status of the Keoladeo National Park, Bharatpur, Rajasthan, India (April 2009). US Geological Survey Science Investigation Report, 5193. Pp. 5193-5200. U.S. Geological Survey, Reston 2009.

Mielke M.S., De Almeida A.A.F., Gomes F.P. et al.: Leaf gas exchange, chlorophyll fluorescence and growth responses of Genipa americana seedlings to soil flooding. - Environ. Exp. Bot. 50: 221-231, 2003

Mielke M.S., Matos E.M., Couto V.B. et al.: Some photosynthetic and growth responses of Annona glabra L. seedlings to soil flooding. - Acta Bot. Bras. 19: 905-911, 2005.

Murchie E.H., Lawson T.: Chlorophyll fluorescence analysis: a guide to good practice and understanding some new applications. - J. Exp. Bot. 64: 3983-98, 2013.

Naumann J.C., Young D.R., Anderson J.E.: Leaf chlorophyll fluorescence, reflectance, and physiological response to freshwater and saltwater flooding in the evergreen shrub, Myrica cerifera. - Environ. Exp. Bot. 63: 402-409, 2008.

Nema A.G., Khare A.K.: Effect of waterlogging on some forest plants. - J. Trop. Forestry 8: 187-188., 1992.

Newsome R.D., Kozlowski T.T., Tang Z.C.: Response of Ulmus americana seedlings to flooding of soil. - Can. J. Bot. 60: 1688-1695, 1982.

Oliveira V.C., Joly C.A.: Flooding tolerance of Calophyllum brasiliense Camb. (Clusiaceae): Morphological, physiological and growth responses. - Trees 24: 185-193, 2010. 
Panwar J., Tarafdar J.C.: Arbuscular mycorrhizal fungal dynamics under Mitragyna parvifolia (Roxb.) Korth. in Thar Desert. - Appl. Soil Ecol. 34: 200-208, 2006.

Papageorgiou G.C., Govindjee.: Photosystem II fluorescence: slow changes - scaling from the past. - J. Photoch. Photobio. B. 104: 258-270, 2011 .

Parolin P.: Morphological and drought and physiological adjustments in seedlings of Amazonian floodplain to waterlogging trees. - Oecologia 128: 326-335, 2001.

Parry M.L., Canziani O.F., Palutikof J.P. et al. (ed.): Climate Change 2007: Impacts, Adaptation and Vulnerability. Contribution of Working Group II to the Fourth Assessment Report of the Intergovernmental Panel on Climate Change. Pp. 976. Cambridge University Press, Cambridge 2007.

Percival G.C., Fraser G.A., Oxenham G.: Foliar salt tolerance of Acer genotypes using chlorophyll fluorescence. - J. Arboricult. 29: 61-65, 2003.

Perkins L.B., Johnson D.W., Nowak R.S.: Plant-induced changes in soil nutrient dynamics by native and invasive grass species. - Plant Soil 345: 365-374, 2011.

Pezeshki S.R.: Differences in patterns of photosynthetic $\mathrm{CO}_{2}$ responses to hypoxia in flood-tolerant and flood-sensitive tree species. - Photosynthetica 28: 423-430, 1993.

Pezeshki S.R.: Plant response to flooding. - In: Wilkinson R.E (ed.): Plant Environment Interactions. Pp. 289-321. Marcel Dekker, New York 1994.

Pezeshki S.R.: Wetland plant responses to soil flooding. Environ. Exp. Bot. 46: 299-312, 2001.

Poot P., Lambers H.: Growth responses to waterlogging and drainage of woody Hakea (Proteaceae) seedlings, originating from contrasting habitats in south-western Australia. - Plant Soil 253: 57-70, 2003.

Pucciariello C., Voesenek L.A., Perata P. et al.: Plant responses to flooding. - Front. Plant Sci. 5: 226, 2014.

Sairam R.K., Dharmar K., Chinnusamy V. et al.: Waterlogginginduced increase in sugar mobilization, fermentation, and related gene expression in the roots of mung bean (Vigna radiata). - J. Plant Physiol. 166: 602-616, 2009.

Schaffer B., Andersen P.C., Ploetz R.C.: Responses of fruit crops to flooding. - In: Janick J. (ed.): Horticultural Reviews, Vol. 13. Pp. 257-313. John Wiley \& Sons, New York 1992.

Simova-Stoilova L., Demirevska K., Kingston-Smith A. et al.: Involvement of the leaf antioxidant system in the response to soil flooding in two Trifolium genotypes differing in their tolerance to waterlogging. - Plant Sci. 183: 43-49, 2012.

Smethurst C.F., Shabala S.. Screening methods for waterlogging tolerance in lucerne: comparative analysis of waterlogging effects on chlorophyll fluorescence, photosynthesis, biomass and chlorophyll content. - Funct. Plant Biol. 30: 335-343, 2003.

Stolzy L.H., Sojka R.E.: Effects of flooding on plant diseases. In: Kozlowski T.T. (ed.): Flooding and Plant Growth. Pp. 221264. Academic Press, New York - London 1984.

Tang Z.C., Kozlowski T.T.: Some physiological and growth response of Betula papyrifera seedlings to flooding. - Physiol. Plantarum 55: 415-420, 1982.

Thomson C.J., Atwell B.J., Greenway H.: Response of wheat seedlings to low $\mathrm{O}_{2}$ concentrations in nutrient solution: II. $\mathrm{K}^{+} / \mathrm{Na}^{+}$selectivity of root tissue of different age. - J. Exp. Bot. 40: 993-999, 1989.

van Kleunen M.: Conservation physiology of plants. - Conserv. Physiol. 2: 1-2, 2014.

Verma K.K., Singh M., Verma C.L.: Developing a mathematical model for variation of physiological responses of Jatropha curcas leaves depending on leaf positions under soil flooding. - Acta Physiol. Plant. 34: 1435-1443, 2012.

von Caemmerer S., Farquhar G.D.: Some relationships between the biochemistry of photosynthesis and the gas exchange of leaves. - Planta 153: 376-387, 1981.

Webb J.A., Fletcher R.A.: Paclobutrazol protects wheat seedlings from injury due to waterlogging. - Plant Growth Regul. 18: 201-206, 1996.

Yamamoto F, Sakata T, Terazawa K.: Physiological, morphological and anatomical response of Fraxinus mandshurica seedlings to flooding. - Tree Physiol. 15: 713-719, 1995.

Yang Y, Li C, Li J. et al.: Growth dynamics of Chinese wingnut (Pterocarya stenoptera) seedlings and its effects on soil chemical properties under simulated water change in the Three Gorges Reservoir Region of Yangtze River. - Environ. Sci. Pollut. Res. Int. 20: 7112-7123, 2013.

Yetisir H., Çeliskan M.E., Soylu S. et al:: Some physiological and growth responses of watermelon [Citrullus lanatus (Thunb.) Matsum. and Nakai] grafted onto Lagenaria siceraria to flooding. - Environ. Exp. Bot. 58: 1-8, 2006.

Yordanova R.Y., Popova L.P.: Photosynthetic response of barley plants to soil flooding. - Photosynthetica 39: 515-520, 2001. 